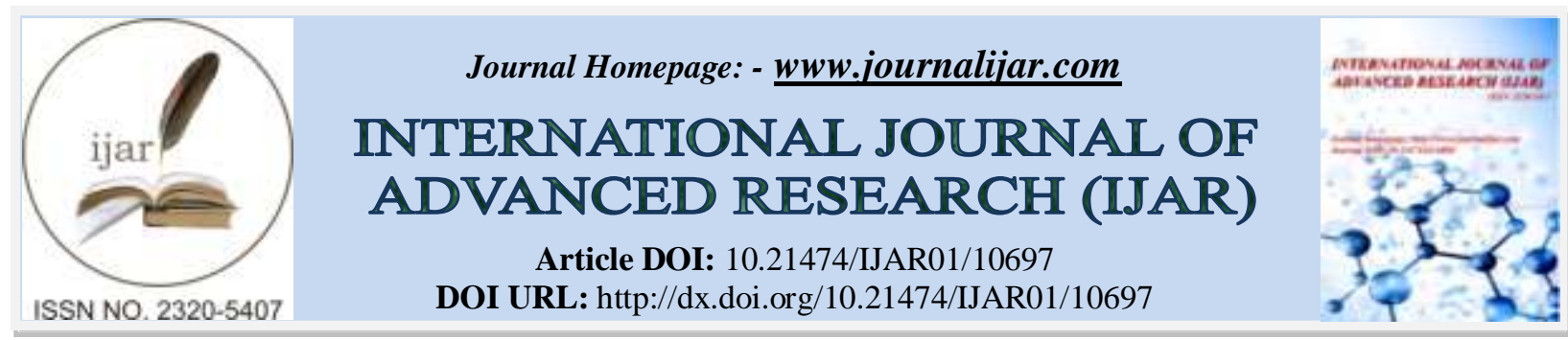

RESEARCH ARTICLE

\title{
PURIFICATION AND ENZYMATIC ACTIVITY OF CYCLOPHILIN PROTEIN FROM TRITICUM AESTIVUM PLANT
}

\author{
Ankita Gupta ${ }^{1}$ and Sanjeev Dubey ${ }^{2}$ \\ 1. Department of Biotechnology, A.P.S. University Rewa, M.P. \\ 2. Department of Botany, Govt. Model Science College, Rewa, M.P.
}

\section{Manuscript Info}

….......................

Manuscript History

Received: 20 January 2020

Final Accepted: 22 February 2020

Published: March 2020

Key words:-

Purification, PCR, Protein, PPiase

\section{Abstract}

Immunophilins, a large family of proteins constitute Cyclophilins, FKBPs and Parvulins. Cyclophilin proteins in Triticum aestivum possessing peptidyl prolyl cis trans isomerase(E.C. 35.1.2.8) activity and due to this activity cis trans isomerization of peptidyl prolyl bond observed.cDNA library was used to chosen Cyclophilin A like protein from $T$. aestivum .Primers used in the study to amplify DNA by PCR and E. coli DH5 $\alpha$ used for cloning. The amplified Cyclophilin (CyPA) PCR product was gel purified and concentrations were measured by nanodrop spectrometer as $10 \mathrm{ng} / \mu \mathrm{l}$ for Cyclophilin (CyPA)gene . Purification of CYP A protein was done using Ni-NTA chromatography, the purified CYPA through Ni-NTA column migrated at about $21 \mathrm{kDa}$ respectively in SDS-PAGE and confirmation of recombinant CYPA protein by Western blot analysis observed a 21 $\mathrm{kDa}$ band that reacted with anti-His antibodies then Identification of CYPA proteins by mass spectrometry was done. The activity of PPiase was measured by using the coupled assay ,the synthetic peptide Nsuccinyl-Ala-Xaa-Pro-Phe-p-nitroanilide was used as substrate. In this study we revealed that amplified Cyclophilin (CyPA) PCR product concentrations were measured by nanodrop spectrometer as $10 \mathrm{ng} / \mu \mathrm{l}$ for Cyclophilin (CyPA)gene and hyperbolic regression of CYPA protein showed $\mathrm{Vm}=0.7094 \pm 0.08761 \mathrm{~min} / \mu \mathrm{g}, \mathrm{Km}=0.7094 \pm 0.08761 \mu \mathrm{M}$.

Copy Right, IJAR, 2020,. All rights reserved.

\section{Introduction:-}

Triticum aestivum is very important cereal crop in India , is cultivated for food since prehistoric times by the peoples of the temperate zones and now, the most important grain crop of those regions.T.aestivum is staple food for 35 percent of the world's population,is protein rich food than any other crop.. Cyclophilin protein of T.aestivum plant possesses Peptidyl prolyl cis trans isomerase(PPiaes)activity. Cyclophilins represent a subgroup of a large family of proteins called immunophilins, which also include FKBPs and Parvulins. The enzymatic activity of cyclophilins, the cis-trans isomerisation of peptide bonds preceding proline residues, suggests a role in ensuring the correct and efficient folding of nascent proteins.. Peptidyl prolyl cis-trans isomerases (PPIases; also named foldases, maturases, rotamase ) (PPIases; EC 5.2.1.8) catalyse the cis-trans isomerisation of the peptidyl-prolyl peptide bond in oligopeptides and activity is particularly significant during stress conditions where a change in physiological condition denatures the correctly folded protein.. By using the latest biotechnological tools, we can develop individual gene clones and analyze the specific role of gene/proteins in the plants. 


\section{Materials and Methods:-}

Plant material and baterial strain used:

T.aestivum seeds were germinated and E. coli DH5 $\alpha$ and Prokaryotic expression system pET_28a was used for cloning.

Polymerase chain reaction amplification of Triticum aestivum cyclophilin-A (CypA) genes:

The sample of plant material $(50 \mathrm{mg})$ was taken and Total RNA was isolated with the TRIzol followed by cDNA synthesised. Primers used in the study were custom synthesized from GeNei, Bangalore (MERCK) and used to amplify DNA by PCR. Triticum aestivum cDNA was used as a template for amplification of Cyclophilin (CypA) gene using forward primer and reverse primer.

\section{Plasmid isolation and Restriction enzyme digestion:}

The plasmid pET28a (+) was streaked onto an LB agar kanamycin plate $(30 \mu \mathrm{g} / \mathrm{ml})$ and kept overnight for incubation at $37{ }^{\circ} \mathrm{C}$. Isolated colonies were inoculated in $10 \mathrm{ml} \mathrm{LB}$ broth containing kanamycin and incubated overnight at 37 ${ }^{\circ} \mathrm{C}$ in a shaker incubator@ 180rpm. Plasmid DNA isolation was performed by alkaline lysis method .About $1 \mu \mathrm{g}$ PCR product $(2 \mu \mathrm{g} / 100 \mu \mathrm{l})$ and $1 \mu \mathrm{g}$ plasmid DNA $(2 \mu \mathrm{g} / 80 \mu \mathrm{l})$ were double digested by NheI and HindIII for 5 and 1 hour respectively. Ligation of NheI and HindIII digested CypA gene in the pET28a vector was done.

\section{Expression and purification of CYPA protein: \\ Induction:}

The T7 express lys $\square$ competent E. coli cells were used for the CYPA expression. The recombinant CypA-pET28a (+) plasmid DNA was transformed to the T7 express lys $\square$ competent E. coli cells as per standard protocol and plated on kanamycin $(30 \mu \mathrm{g} / \mathrm{ml})$ and chloramphenicol $(10 \mu \mathrm{g} / \mathrm{ml})$ plates. A single colony from the plate was inoculated into $10 \mathrm{ml} \mathrm{LB}$ broth with antibiotics and grown in a shaker incubator at $37^{\circ} \mathrm{C} / 180 \mathrm{rpm}$. Next day, overnight culture was diluted in fresh media (1:100) and incubated for 3 to $3 \frac{1}{2}$ hour until OD 600 reached 0.4 to 0.6 . After that, the culture was induced by IPTG to a final concentration of $1 \mathrm{mM}$ for 3 hours at $37^{\circ} \mathrm{C}$.

\section{SDS-PAGE analysis to see the level of expression:}

The gel casting platforms were assembled, and the bottom of the assembly was sealed with agarose. $10 \%$ and $5 \%$ acrylamide was used in separating and stacking gels respectively. The uninduced and induced pellets were mixed with $100 \mu \mathrm{l}$ of the $2 \mathrm{X}$ sample buffer (with B-mercaptoethanol), boiled for $5 \mathrm{~min}$ and loaded into the SDS gel along with a marker. The electrophoresis was performed at 50 volts and 100 volts in stacking and separating gel respectively. After the run, the gel was stained with Coomassie Brilliant Blue R-250 stain (Sigma, USA) for 1 hour. The gel was then destained with several changes of a destaining solution containing $5 \%$ acetic acid and photographed.

\section{Purification of CYPA protein:}

As histidine tag was fused with CYPA, the purification was done using Ni-NTA chromatography. The pellet from two-litre culture was thawed on ice and suspended in $20 \mathrm{ml}$ lysis buffer (Buffer A, pH-8.0). Lysozyme was added @ $1 \mathrm{mg} / \mathrm{ml}$ to the cell suspension and incubated on ice for 30 minutes. Cells were lysed by the 10 cycles of sonication with the amplitude of $15 \mu \mathrm{M}$ for $2 \mathrm{~min}$ and an interval of $2 \mathrm{~min}$ between pulses. The unbroken cells were removed by centrifugation at $12,000 \mathrm{rpm} / 20 \mathrm{~min}$ at $4{ }^{\circ} \mathrm{Cand}$ the supernatant was harvested for loading to the columns. $2 \mathrm{ml}$ Ni-NTA agarose slurry was packed in a $20 \mathrm{ml}$ column, washed with 10 volumes of double distilled water and finally equilibrated with 20 volumes of lysis buffer (contains $40 \mathrm{mM}$ imidazole, pH-8.0). The supernatant obtained after centrifugation was loaded to equilibrated Ni-NTA column. Unbound proteins were washed by 20 volumes of lysis buffer (containing 40mM imidazole). The proteins bound to the Ni-NTA column were eluted by elution buffer $\mathrm{C}$ (containing $250 \mathrm{mM}$ imidazole) and collected as $2 \mathrm{ml}$ fractions. The absorbance was measured at OD280, and peak fractions were loaded into the gel along with molecular weight markers.

\section{PPIase activity assay CYPA protein:}

There have been several assays devised to measure PPIase activity based on Fisher et al. (1984). The assay is based on the little difference in absorbance determined for the cis and trans isomers of Suc-Ala-Xaa-Pro-Phe-4nitroanilide. The activity of PPiase was measured by using the coupled assay described by Fischer et al. (1989). The synthetic peptide N-succinyl-Ala-Xaa-Pro-Phe-p-nitroanilide (where Xaa was either leucine, alanine or phenylalanine, as indicated) was used as substrate $(0.25,0.5,1,2,3,4,9$, and $10 \mu \mathrm{M})$. Assays were performed at 10 ${ }^{\circ} \mathrm{C}$ ina1.2-ml volume containing $35 \mathrm{mM}$ Hepes ( $\left.\mathrm{pH} 7.8\right), 30 \mu \mathrm{g}$ substrate peptide and varying concentrations of 
CYPA protein. Reactions were initiated by the addition of $0.4 \mathrm{mg}$ a-chymotrypsin and were monitored by measuring the absorbance at $390 \mathrm{~nm}$ for $4 \mathrm{~min}$. The enzyme kinetic analysis was done, and the relation between velocity (v) substrate concentration (S) through the Michaelis-Menten equation.

\section{Results:-}

PCR amplification of Cyclophilin (CyPA) gene:

The purity of the isolated RNA Triticum aestivum was checked by measuring the absorbance at 260 and $280 \mathrm{~nm}$. The ratio of OD260/280 was 2.97 which indicate the RNA was pure. The Cyclophilin (CyPA) gene was amplified using the self-designed gene-specific primers from Triticum aestivum cDNA using the PCR. The PCR amplified product migrated as a single band of approximately $513 \mathrm{bp}$ in $1 \%$ agarose gel (Fig.3.1). The concentration of the PCR product was measured by Nanodrop $\sim 50 \mathrm{ng} / \mu \mathrm{l}$.

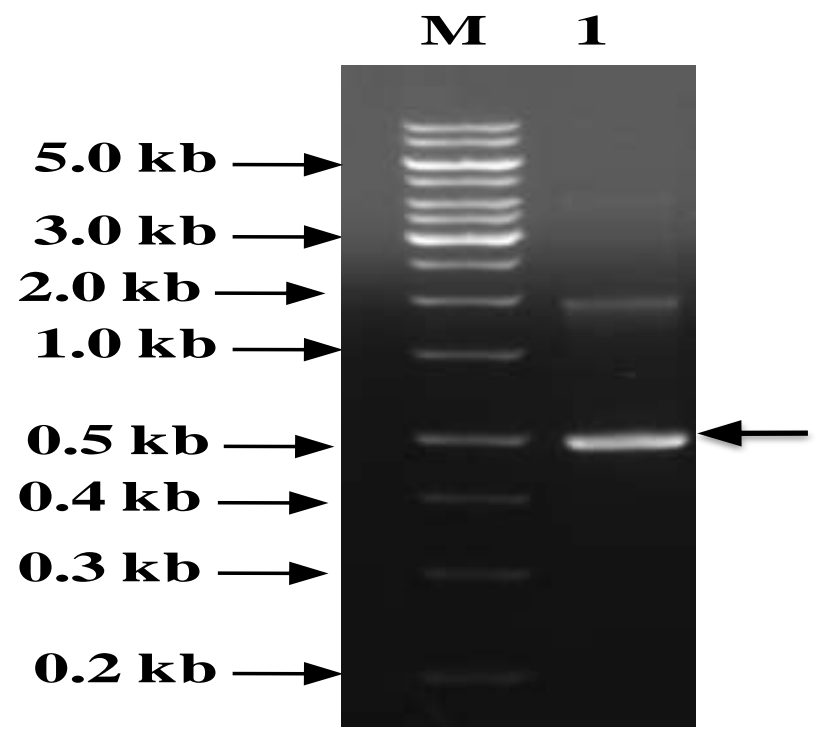

Figure 1:- Agarose gel (1\%) electrophoresis of PCR product CyPA gene. Lane M is a DNA ladder. Lane 1 is expected CyPAPCR product $0.513 \mathrm{~kb}$ (marked by arrow).

\section{Isolation of pET_28 a plasmid:}

Plasmid concentration was found to be $125 \mathrm{ng} / \mu \mathrm{l}$ and $1.83 \mathrm{~A} 260 / 280$ ratios further confirmed that the preparation was pure. The gel eluted pET_28c concentrations were measured by nanodrop spectrometer as $15 \mathrm{ng} / \mu \mathrm{l}$.

\section{Expression and purification of CYPA:}

Induction of positive clones:

The conformed recombinant clones were grown upto mid-log phase (OD600 $=0.4-0.6)$ in LB- broth media. The culture IPTG was added the final concentration of $1 \mathrm{mM}$. The cultures were again incubated for $3 \mathrm{hrs}$ with shaking condition. Following addition of IPTG, an additional protein band appeared in the induced culture which was absent in uninduced lane. The size of that band was approximated by the molecular weight markers and was about $21 \mathrm{kDa}$ (Fig.2 lane UN and IN).

\section{Purification and SDS-PAGE analysis of CYPA:}

The CYPA proteins were purified by Ni-NTA affinity chromatography. The purified CYPA through Ni-NTA

\begin{tabular}{|l|l|}
\hline \multicolumn{1}{|c|}{ Plots } & \multicolumn{1}{c|}{ CYPA } \\
\hline \multirow{2}{*}{ Hanes Plot } & $\mathrm{Vmax}=0.7746 \mathrm{~min} / \mu \mathrm{g}$ \\
\cline { 2 - 2 } & $\mathrm{Km}=1.456 \mu \mathrm{M}$ \\
\hline \multirow{2}{*}{ Hyperbolic Regression Analysis } & $\mathrm{Vmax}=0.7094 \pm 0.08761 \mathrm{~min} / \mu \mathrm{g}$ \\
\cline { 2 - 2 } & $\mathrm{Km}=1.133 \pm 0.3052 \mu \mathrm{M}$ \\
\hline
\end{tabular}

column migrated at about $21 \mathrm{kDa}$ respectively in SDS-PAGE. 


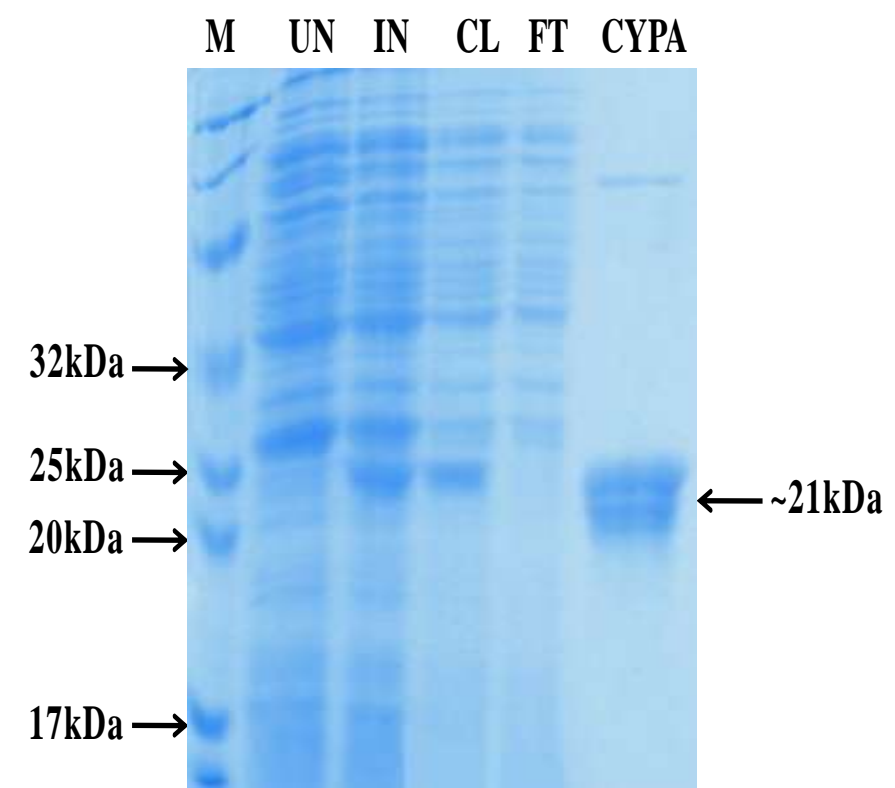

Figure 2:- Expression and purification of recombinant Triticum aestivum CYPA in E. coli.

\section{Enzyme activity of recombinant CYPA proteins:}

The velocity (v) of an enzyme-catalyzed reaction is hyperbolically related to the substrate concentration (S) through the well-known equation of Michaelis-Menten given below:

$\mathbf{v}=\mathbf{V}_{\max }[\mathbf{S}] /\left(\mathbf{K}_{\mathbf{m}}+[\mathbf{S}]\right)$

$\mathrm{V}_{\max }$ and $\mathrm{K}_{\mathrm{m}}$ are kinetic constants characteristic of the particular enzyme and substrate. These constants are estimated by experiments in which $[\mathrm{S}]$ is varied and $\mathrm{v}$ calculated .

Table:- $\mathrm{V}_{\mathrm{m}}$ and $\mathrm{K}_{\mathrm{m}}$ calculation for the three purified enzymes.

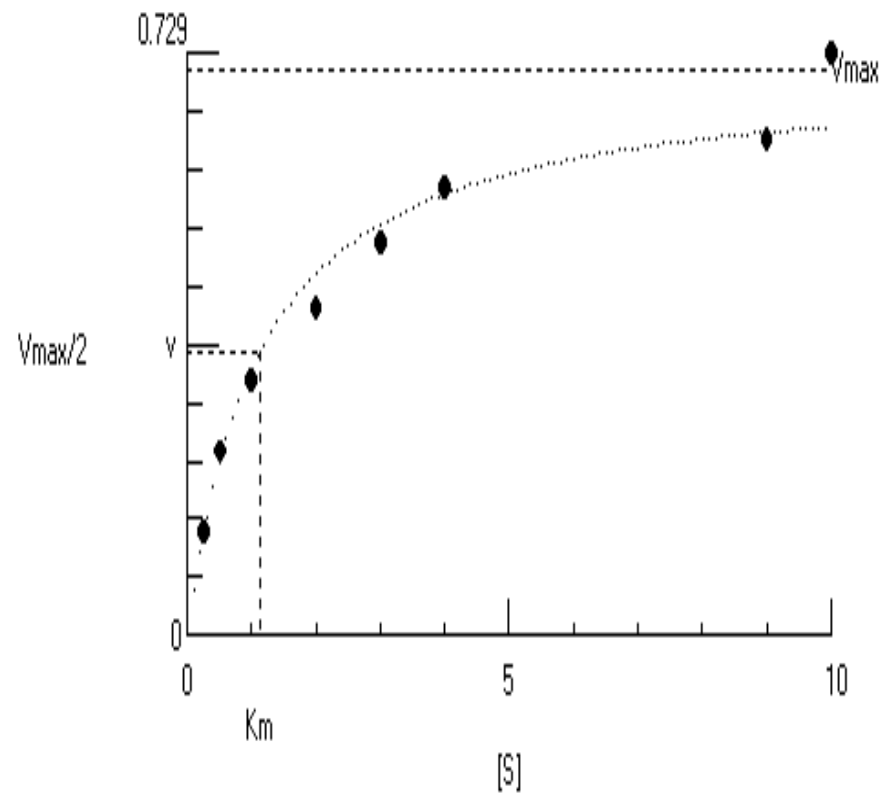

Figure 3:- Enzyme kinetics of analysis recombinant purified CYPA protein. Michaelis-Menten fit based on measured activities of CYPA with the artificial peptide substrates Suc-Ala-Ala-Pro-Phe-pNA. The hyperbolic regression of CYPA protein showed $\mathrm{Vm}=0.7094 \pm 0.08761 \mathrm{~min} / \mu \mathrm{g}, \mathrm{Km}=0.7094 \pm 0.08761 \mu \mathrm{M}$. Data represent average values and standard deviations from duplicate measurements. 


\section{Discussion:-}

Different organisms have different numbers of CYPs. E. coli, S. cerevisiae, and human contain 2, 8, and 16 CYP genes, respectively.However, plant genomes contain relatively larger numbers of CYP For example; Arabidopsis and rice genome have 35 and 28 CYPs, respectively(Ahn et al., 2010; Trivedi et al., 2012a).

The present research focuses on a genome-wide scan and systematic characterisation of the Triticum aestivum . A major aim of this thesis was to test the hypothesis that genes encoding cyclophilins in wheat, and to identify that may be potentially associated with enzymatic and chaperone roles in protein folding, plant development, stress tolerance. The experimental molecular gene cloning of cyclophilins gene from wheat was done in E. coli. After the successful gene cloning protein isolation and characterisation, it is enzymatic by experimental methods and identification of the corresponding gene in Triticum aestivum by biochemical approaches were other major aims.

1. Ahn, J. C., Kim, D. W., You, Y. N., Seok, M. S., Park, J. M., Hwang, H., Kim, B. G., Luan, S., Park, H. S. and Cho, H. S. (2010). Classification of rice (Oryza sativa L. Japonica nipponbare) immunophilins (FKBPs, CYPs) and expression patterns under water stress. BMC Plant Biol,10, 253.

2. Arevalo-Rodriguez, M., Wu, X., Hanes, S. D. and Heitman, J. (2004). Prolyl isomerases in yeast. Front Biosci,9, 2420-2446.

3. Ashraf, M., Athar, H., Harris, P. and Kwon, T. (2008). Some prospective strategies for improving crop salt tolerance. Advances in agronomy,97, 45-110.

4. Chen, A. P., Wang, G. L., Qu, Z. L., Lu, C. X., Liu, N., Wang, F. and Xia, G. X. (2007). Ectopic expression of ThCYP1, a stress-responsive cyclophilin gene from Thellungiella halophila, confers salt tolerance in fission yeast and tobacco cells. Plant Cell Rep,26, 237-245.

5. Chou, I. T. and Gasser, C. S. (1997). Characterization of the cyclophilin gene family of Arabidopsis thaliana and phylogenetic analysis of known cyclophilin proteins. Plant molecular biology,35, 873-892.

6. Trivedi, D. K., Ansari, M. W., Dutta, T., Singh, P. and Tuteja, N. (2013). Molecular characterization of cyclophilin A-like protein from Piriformospora indica for its potential role to abiotic stress tolerance in E. coli. BMC Res Notes, 6, 555.

7. Handschumacher, R. E., Harding, M. W., Rice, J., Drugge, R. J. and Speicher, D. W. (1984). Cyclophilin: a specific cytosolic binding protein for cyclosporin A. Science,226, 544-547. 